\title{
Antifouling phenyl ethers and other compounds from the invertebrates and their symbiotic fungi collected from the South China Sea
}

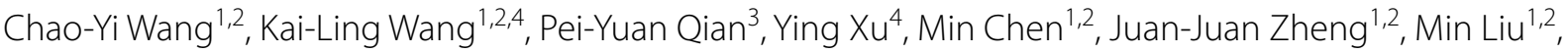 \\ Chang-Lun Shao ${ }^{1,2^{*}}$ and Chang-Yun Wang ${ }^{1,2,5^{*}}$
}

\begin{abstract}
Marine organism-derived secondary metabolites are promising potential sources for discovering environmentally safe antifouling agents. In present study, 55 marine secondary metabolites and their synthesized derivatives were tested and evaluated for their antifouling activities and security. These compounds include 44 natural products isolated from marine invertebrates and their symbiotic microorganisms collected from the South China Sea and 11 structural modified products derived from the isolated compounds. The natural secondary metabolites, covering phenyl ether derivatives, terpenoids, 9, 11-secosteroids, anthraquinones, alkaloids, nucleoside derivatives and peptides, were isolated from two corals, one sponge and five symbiotic fungi. All of the isolated and synthesized compounds were tested for their antifouling activities against the cyprids of barnacle Balanus (Amphibalanus) amphitrite Darwin. Noticeably, five phenyl ether derivatives $(\mathbf{9}, \mathbf{1 1}, \mathbf{1 3}-\mathbf{1 5})$ exhibited potent anti-larval settlement activity with the $\mathrm{EC}_{50}$ values lower than $3.05 \mu \mathrm{M}$ and the $\mathrm{LC}_{50} / \mathrm{EC}_{50}$ ratios higher than 15 . The study of structure-activity relationship (SAR) revealed that the introduction of acetoxy groups and bromine atoms to phenyl ether derivatives could significantly improve their antifouling activities. This is the first report on the SAR of phenyl ether derivatives on antifouling activity against barnacle B. amphitrite. The polybrominated diphenyl ether derivative, 2, 4, 6, 2', 4', 6'-hexabromo-diorcinol (13), which displayed excellent antifouling activity, was considered as a promising candidate of environmentally friendly antifouling agents.
\end{abstract}

Keywords: Antifouling, Anti-larval settlement, Balanus amphitrite, Marine natural product, Phenyl ether derivative

\section{Introduction}

Marine biofouling is still a thorny issue that brings tremendous losses in both marine technical and economic fields around the world. Biofouling is a natural process that involves the settlement and growth of fouling organisms such as barnacles, bryozoans, hydroids and mussels on natural or man-made structures and finally leads to material deterioration (Pérez et al. 2014; Li et al. 2013).

\footnotetext{
*Correspondence: shaochanglun@ouc.edu.cn; changyun@ouc.edu.cn ${ }^{1}$ Key Laboratory of Marine Drugs, School of Medicine and Pharmacy, The Ministry of Education of China, Ocean University of China, 5 Yushan Road, Qingdao 266003, People's Republic of China

Full list of author information is available at the end of the article
}

In the early years, paints containing toxic materials like copper, lead, mercury and arsenic were used to control biofouling until organotins such as tributyltin (TBT) and triphenyltin were introduced in the 1960s (Qian et al. 2010; Omae 2003). However, because of the hypertoxicity to the marine ecological environment, fishery and aquaculture (Rittschof 2001), an increasing number of countries have ratified an international treaty to ban the application of antifouling coatings based on organotin compounds since early 2008 (Qian et al. 2010; Faÿ et al. 2007; Kitano et al. 2011). Biocide-based antifouling paints including Irgarol 1051, chlorothalonil and dichlofluanid were introduced as alternatives to organotins in 
antifouling products, but have also been found that they accumulate in marine environment and are deleterious to marine organisms (Konstantinou and Albanis 2004). Thus, the demand for environmentally benign, non-toxic or low toxic antifouling agents is urgently required.

In the past decades, great attention has been paid to search for natural products as antifoulants (Raveendran and Mol 2009). It is well known that marine organisms (macro- and microorganisms) have been shown to be rich sources of bioactive secondary metabolites. Many of marine macroorganisms are able to stay free from biofouling and their secondary metabolites are believed to be chemical defensive substances. These natural compounds are easily biodegradable and leave no residue in the environment, thus have been considered as a potential resource for environmentally friendly natural antifouling agents (Culioli et al. 2008; Gao et al. 2014). In recent years, marine microorganisms, such as fungi and bacteria, have also been explored for antifouling agents, because they could supply large amount of natural products (Fusetani 2011; Newman and Cragg 2004). The marine natural products with antifouling activity identified so far cover variety of structural types, including phenolics, terpenoids, steroids, furanones, alkaloids, peptides, lactones and fatty acids (Qian et al. 2010; Fusetani 2011; Raveendran and Mol 2009).

The barnacle Balanus (Amphibalanus) amphitrite Darwin is a globally distributed biofouler and also be used as a model species in intertidal ecology and larval settlement studies (Chen et al. 2011). Over the years, a program initiated by our group focused on marine natural compounds with antifouling activity isolated from the invertebrates and their symbiotic microorganisms collected from the South China Sea (Shao et al. 2011a, 2011b, 2015; Han et al. 2010; Sun et al. 2010, 2012; Wang et al. 2011; Zhou et al. 2011; Li et al. 2012; Kong et al. 2012; Chen et al. 2014c; Liu et al. 2014b). Many compounds were found to inhibit the larval settlement of barnacle $B$. amphitrite significantly, such as dihydroquinolin-2-one-containing alkaloids from the gorgonianderived fungus Scopulariopsis sp. (Shao et al. 2015), the briarane-type diterpenoids from the gorgonian Dichotella fragilis (Zhou et al. 2011) and Subergorgia mollis (Kong et al. 2012), and the resorcylic acid lactones from the marine-derived fungus Cochliobolus lunatus (Shao et al. 2011b; Liu et al. 2014b). In our previous report, 49 secondary metabolites isolated from Chinese marine organisms were tested for their antifouling activities $(\mathrm{Li}$ et al. 2013). In present study, 55 natural products and synthesized derivatives, derived from two gorgonians, one sponge, and five symbiotic fungi collected from the South China Sea, were tested for their anti-larval settlement activities against B. amphitrite. Specifically, the primary structure-activity relationships (SAR) on antifouling activity of phenyl ether derivatives were investigated and discussed.

\section{Materials and methods \\ Gorgonian coral, sponge and fungal materials}

Eight marine organisms from the South China Sea were selected for this study, including two gorgonian corals (Anthogorgia ochracea GXWZ-07, Subergorgia suberosa GXBHWZ-22), one sponge (Carteriospongia foliascens WMS-8) and five coral-derived fungi (Aspergillus sp. XS-20090066, Aspergillus versicolor XS-20090067, Aspergillus sp. XS-20090B15, Eurotium sp. XS-2009-00E6, Aspergillus elegans ZJ-2008010). The gorgonians $A$. ochracea GXWZ-07 and S. suberosa GXBHWZ-22 were collected from Weizhou Island coral reef in Apr. 2011, and were identified by Dr. Xiu-Bao Li and Prof. Hui Huang, the South China Sea Institute of Oceanology, Chinese Academy of Science. The sponge Carteriospongia foliascens WMS-8 was obtained from Sanya coral reef in Nov. 2006, and was identified by Dr. Nicole J. de Voogd, the National Natural Biodiversity Research Center of Netherlands. The fungi Aspergillus sp. XS-20090066 and Aspergillus versicolor XS-20090067, with the Genebank accession numbers of HM535361 and AY373880, respectively, were isolated from the inner part of the fresh gorgonian Dichotella gemmacea collected from Xisha Islands coral reef in Dec. 2009. The fungus Aspergillus sp. XS-20090B15 (Genebank accession No. HM991281) was derived from the gorgonian Muricella abnormaliz collected from Xisha Islands coral reef in Dec. 2009. The fungus Eurotium sp. XS-2009-00E6 (GenBank accession No. HM991283) was derived from the Xisha Islands gorgonian Subergorgia suberosa collected in Dec. 2009. The fungus Aspergillus elegans ZJ-2008010 (Genbank accession No. JF694928) was cultured from a soft coral Sarcophyton sp. collected from Weizhou Island coral reef in Sep. 2008. The fungi were identified according to their morphological traits and a molecular biological protocol by amplification and sequencing of the DNA sequences of the ITS region of the rRNA gene. The sequence data were submitted to NCBI GenBank. All of the five fungi (Aspergillus sp. XS-20090066, Aspergillus versicolor XS-20090067, Aspergillus sp. XS-20090B15, Eurotium sp. XS-2009-00E6, Aspergillus elegans ZJ-2008010) were deposited at the Key Laboratory of Marine Drugs, Ocean University of China, Qingdao, PR China (WDCM collection \#1131).

\section{Isolation, synthesis and identification of compounds}

The natural compounds 1-6, 16-29, 32-50, 53-55 were isolated from two gorgonians, one sponge and five coralderived fungi using silica gel column chromatography, 
sephadex column chromatography and semi-preparative HPLC. The synthesized derivatives 7-15, 30-31, 51-52 were obtained by alkylation, acylation, or bromination reactions of the corresponding isolated compounds. All of the structures of these compounds were determined by NMR and MS (see Additional file 1). The structures of all compounds are available in the (Additional file 1: Figs. S1-S7).

\section{Larval culture of barnacle Balanus (Amphibalanus) amphitrite}

Adults of the barnacle B. amphitrite Darwin were collected from the pilings of the Sai Kung Pier in Hong Kong $\left(22^{\circ} 21^{\prime} \mathrm{N}, 114^{\circ} 15^{\prime} \mathrm{E}\right)$, and then placed in a glass tank filled with $0.22 \mu \mathrm{m}$ fresh filtered seawater to release the nauplii. The newly released nauplii were screened with the aperture of $90 \mu \mathrm{m}$. The newly released nauplii were raised in filtered seawater (FSW) at $28^{\circ} \mathrm{C}$ with mild aeration and fed with Chaetoceros gracilis Schutt at $1 \times 10^{6}$ cells $\mathrm{ml}^{-1}$. The nauplius larvae transformed into cyprids (ready to attach and metamorphose) after 3.5 days. Newly transformed cyprids were kept in filtered seawater at $4{ }^{\circ} \mathrm{C}$ overnight before being used in the anti-larval settlement bioassay.

\section{Anti-larval settlement bioassay}

The antifouling activity was evaluated as larval settlement inhibition against the cyprids of barnacle $B$. amphitrite using 24-well polystyrene plates (Nunc, Naperville, CA, USA). Each compound was dissolved in a stock solution of DMSO with the concentration of $50 \mathrm{mg} \mathrm{ml}^{-1}$, and then diluted 1000 times with FSW to $50 \mu \mathrm{g} \mathrm{ml}^{-1}$. The compound was further transferred into FSW to make up the following test solution with the concentrations ranging from 25 to $0.50 \mu \mathrm{g} \mathrm{ml}^{-1}$. One millilitre of the test solution and 16-20 larvae were allocated to each well of the 24-well plate. Each concentration had three replicate wells. The plates were cultivated in darkness for $48 \mathrm{~h}$ at $28{ }^{\circ} \mathrm{C}$. The effects of the test compounds against the larvae settlement were determined by examining the plates under a dissecting microscope to check for (1) settled larvae (attached and metamorphosed), (2) swimming larvae, as well as (3) any possible toxic effects of the treatments (dead and paralyzed). The number of the settled larvae was expressed as a percentage of the total number of larvae per well. Each compound was tested by triplicate experiments using three different batches of larvae. The wells containing Sea-Nine $211^{\mathrm{TM}}$ (Jacobson and Willingham 2000) at the concentration of $1.23 \mu \mathrm{g} \mathrm{ml} \mathrm{m}^{-1}$ (the $\mathrm{EC}_{50}$ value against $B$. amphitrite) were used as a positive control, while those containing DMSO-FSW ( $v / v$ 1:1000) served as the negative controls (Wang et al. 2015; Xu et al. 2010).

\section{Calculation of $\mathrm{EC}_{50}$ and $\mathrm{LC}_{50}$ values of each compound}

The $\mathrm{EC}_{50}$ and $\mathrm{LC}_{50}$ values of each compound were calculated according to the records of anti-larval settlement experiments. The $\mathrm{EC}_{50}$ was calculated as the concentration where $50 \%$ of the larvae were inhibited to settle in comparison with the negative control, while $\mathrm{LC}_{50}$ was calculated as the concentration where $50 \%$ of the larvae were dead. Then a concentration-response curve was plotted and a tread line was set up.

\section{Brine shrimp lethality bioassay}

The brine shrimp lethality bioassay on Artemia salina was performed to predict the toxicity of the compounds. The test was conducted using 24-well plate as described previously according to standard protocols (Solis et al. 1993; Meyer et al. 1982). The wells containing FSWDMSO ( $/ / v$ 1:1000) served as the negative controls. Adriamycin was used as a positive control. There were three replicate wells per concentration, and each bioassay experiment had three replicates using three different batches of brine shrimp.

\section{Results}

\section{Isolated and synthesized compounds}

Fifty-five compounds were obtained for the antifouling bioassay. Among them, 44 natural products were isolated from two gorgonians, one sponge and five coral-derived fungi, and 11 synthesized products were obtained by structural modification of the isolated natural compounds. These compounds belong to seven structural types, including phenyl ether derivatives (1-15), terpenoids (16-22), 9, 11-secosteroids (23-31), anthraquinones (32-39), alkaloids (40-47), nucleoside derivatives (48-52), and peptides (53-55) (Fig. 1; Additional file 1).

The phenyl ether derivatives 1-6 (Bunyapaiboonsri et al. 2007; Gong et al. 2011; Chen et al. 2013) were isolated as characteristic secondary metabolites from the fungus Aspergillus sp. XS-20090066. The phenyl ether derivatives 7-14 (Chen et al. 2013) and 15 were synthesized from diorcinol (1) and 4-methoxyacyl-diorcinol (3) by structure modification with alkylation, acylation and bromination reactions. The sesquiterpenoids 1621 (Sato et al. 2013; Koul et al. 1985; Zheng et al. 2014; Nozoe et al. 1984; Talzhanov et al. 2005) were isolated as the characteristic components from the gorgonian $A$. ochracea GXWZ-07. The diterpenoid 22 (Anderson et al. 1994) was isolated from the sponge $C$. foliascens WMS8. The 9,11-secosteroids 23-29 (Liu et al. 2014a; Jäälaid et al. 2001; Aknin et al. 1998; Migliuolo et al. 1992; Zhang et al. 2013) were isolated from the gorgonian S. suberosa GXBHWZ-22, while 30 (Liu et al. 2014b) and 31 (Liu et al. 2014a) were synthetic acetylated derivatives of 29. The anthraquinones 32-34 (Lee et al. 2010; Chen et al. 


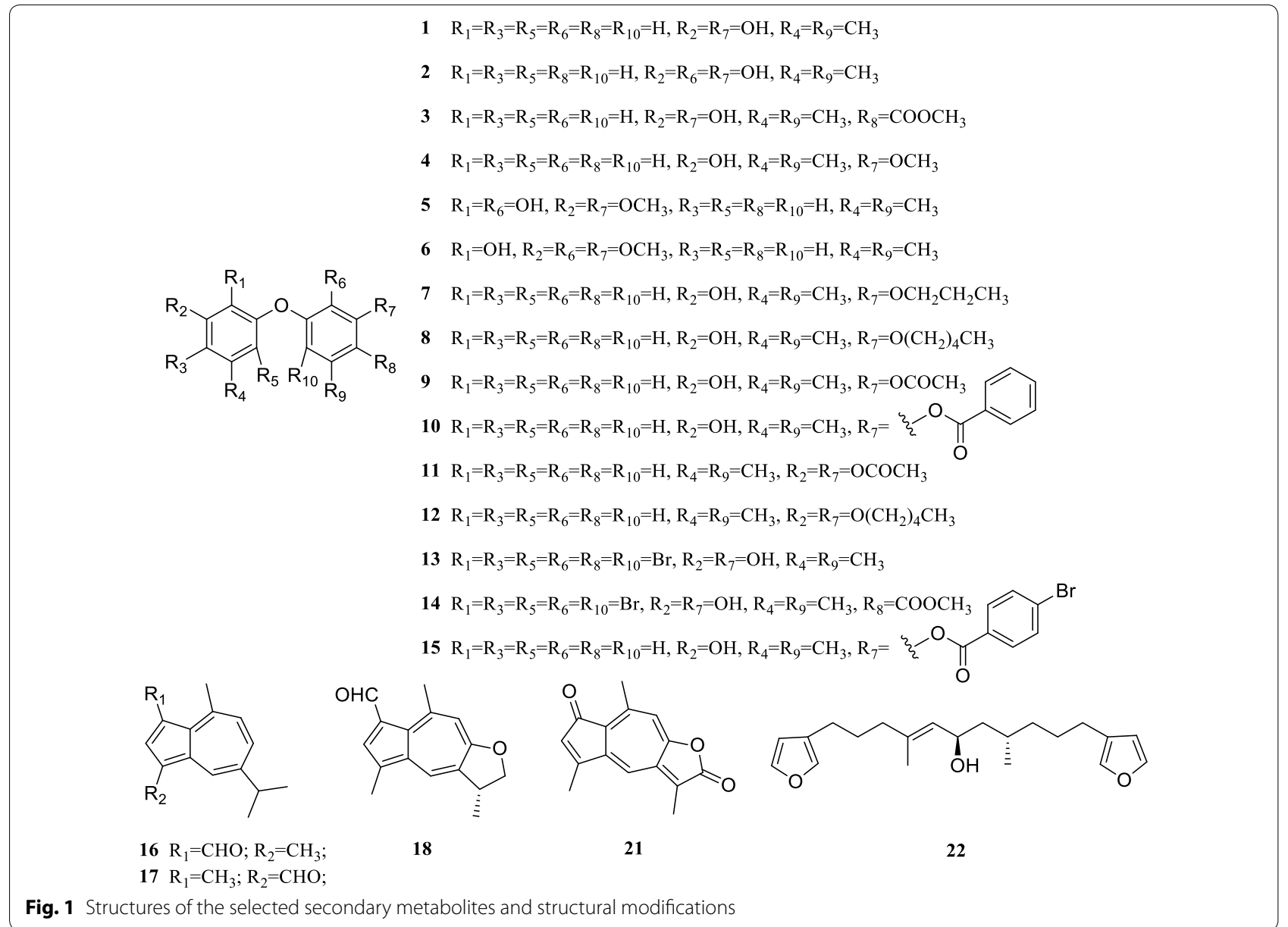

2014e; Ren and Liu 2011) were isolated from the fungus Aspergillus sp. XS-20090066, 35-38 (Slater et al. 1971; Arai et al. 1989) from the fungus Eurotium sp. XS2009-00E6, while 39 (Wright et al. 2009) from the sponge C. foliascens WMS-8. The indole alkaloids 40-45 (Wang et al. 2007; Chen et al. 2014a; Li et al. 2004; Podojil et al. 1979; Nagasawa et al. 1975) were isolated from the fungus Eurotium sp. XS-2009-00E6, and the cytochalasin alkaloids 46 (Zhou et al. 2004), 47 (Naruse et al. 1993) were separated from the fungus A. elegans ZJ-2008010. The nucleoside derivatives 48-50 (Chen et al. 2014b; Jiao et al. 2007) were isolated from the fungus $A$. versicolor XS-20090067, and 51 (Chen et al. 2014b) and $\mathbf{5 2}$ (Chen et al. 2014b) were acetylated derivatives of kipukasins $\mathrm{E}$ (49) and D (50), respectively. The peptides 53-55 (Chen et al. 2014d) were isolated from the fungus Aspergillus sp. XS-2009-0B15 (see Additional file 1).

\section{Screening for compounds with anti-larval settlement activity against $B$. amphitrite}

All of the 55 compounds were firstly tested in the preliminary screening for their antifouling activities. The results indicated that 34 compounds $(\mathbf{1}-\mathbf{1 8}, \mathbf{2 2}, \mathbf{2 3}, \mathbf{2 5}, \mathbf{2 6}, \mathbf{2 8}$ $33,37-39,45-47)$ completely inhibited the larval settlement of B. amphitrite at a concentration of $25.0 \mu \mathrm{g} \mathrm{ml}^{-1}$, which was the standard requirement of a natural antifouling compound established by the U.S. Navy program. Subsequently, the active compounds were further evaluated for their antifouling activities expressed as the $\mathrm{EC}_{50}$ values (Table 1). Of the potential anti-larval settlement compounds, the phenyl ether derivatives, terpenoids and 9,11-secosteroids exhibited strong or moderate activity, while the anthraquinones, alkaloids, nucleoside derivatives and peptides only showed weak or even no activity.

\section{Discussion}

Antifouling activity of phenyl ethers

Anti-larval settlement activity of phenyl ethers against $B$. amphitrite

All of the 15 phenyl ether derivatives showed strong or moderate activity. Noticeably, five phenyl ether derivatives, 9, 11, 13-15 demonstrated strong activity with the $\mathrm{EC}_{50}$ values $\leq 3.05 \mu \mathrm{M}$ lower than the positive control Sea-Nine $211^{\mathrm{TM}}\left(\mathrm{EC}_{50}=4.36 \mu \mathrm{M}\right)$ (Table 1). More 
Table 1 Antifouling activity of 55 compounds against the cyprids of barnacle $B$. amphitrite $\left(\mathrm{EC}_{50}\right.$ in $\left.\mu \mathrm{M}\right)$, toxicity ( $\mathrm{LC}_{50}$ in $\mu \mathrm{M})$ and $\mathrm{LC}_{50} / \mathrm{EC}_{50}$ ratios

\begin{tabular}{|c|c|c|c|}
\hline Compounds & $\mathrm{EC}_{50}$ & $\mathrm{LC}_{50}$ & $\mathrm{LC}_{50} / \mathrm{EC}_{50}$ \\
\hline Diorcinol (1) & 32.6 & $>217$ & $>6.67$ \\
\hline Cordyol C (2) & 57.3 & $>203$ & $>3.54$ \\
\hline 4-Methoxyacyl-diorcinol (3) & 7.43 & $>174$ & $>23.4$ \\
\hline Cordyol E (4) & 31.0 & $>205$ & $>6.61$ \\
\hline 3,3'-O-dimethylviolaceol-I (5) & 18.4 & $>172$ & $>9.35$ \\
\hline Cordyol D (6) & 18.2 & $>164$ & $>9.01$ \\
\hline 3-O-propyl-diorcinol (7) & 9.82 & 112 & 11.4 \\
\hline 3-O-pentyl-diorcinol (8) & 27.9 & $>167$ & $>5.99$ \\
\hline 3-O-acetyl-diorcinol (9) & 3.05 & 64.3 & 21.1 \\
\hline 3-O-benzoyl-diorcinol (10) & 12.6 & $>150$ & $>11.9$ \\
\hline 3,3'-O-diacetyl-diorcinol (11) & 2.23 & 49.4 & 22.2 \\
\hline 3,3'-O-dipentyl-diorcinol (12) & 12.2 & $>135$ & $>11.1$ \\
\hline $2,4,6,2^{\prime}, 4^{\prime}, 6^{\prime}$-Hexabromo-diorcinol (13) & 0.71 & 22.0 & 31.0 \\
\hline $2,6,2^{\prime}, 4^{\prime}, 6^{\prime}$-Pentabromo-4-methoxycarbonyl-diorcinol (14) & 1.17 & 29.3 & 25.0 \\
\hline 3-O-p-Bromobenzoyl-diorcinol (15) & 2.42 & 60.5 & 25.0 \\
\hline 1-Formylguaiazulene (16) & 42.0 & 221 & 5.26 \\
\hline 1-Formyl-4-methyl-7-isopropylazulene (17) & 14.7 & $>236$ & $>16.1$ \\
\hline Ochracenoid A (18) & 83.3 & 208 & 2.5 \\
\hline 3,8-Dimethyl-5-isopropyl-6-formylindenone (19) & $>110$ & $>219$ & UD \\
\hline Ochracenoid B (20) & $>110$ & $>219$ & UD \\
\hline Ketolactone (21) & $>104$ & $>208$ & UD \\
\hline Furospongin-1 (22) & 6.06 & 153 & 25.2 \\
\hline 3ß,6a,11-Trihydroxy-24-nor-9,11-seco-5a-cholest-7-en-9-one (23) & 10.7 & 59.5 & 5.56 \\
\hline (24R)-and(24S)-3 $\beta, 6 a, 11$-Trihydroxy-methyl-9,1 1-seco-5a-cholest-7-en-9-one (24) & $>55.8$ & $>112$ & UD \\
\hline (22E)-3ß,6a,11-Trihydroxy-24-nor-9,11-seco-5a-cholesta-7,22-dien-9-one (25) & 29.9 & 59.8 & 2.00 \\
\hline 3ß,6a,11-Trihydroxy-9,11-seco-5a-cholest-7-en-9-one (26) & 28.6 & 57.6 & 2.01 \\
\hline 3ß,6a,11-Trihydroxy-9,11-seco-5a-cholesta-7,24(28)-dien-9-one (27) & $>56.1$ & $>56.1$ & UD \\
\hline (22E,24R)-3ß,6a,11-trihydroxy-24-Methyl-9,11-seco-5a-cholesta-7,22-dien-9-one (28) & 44.8 & $>56.1$ & $>1.25$ \\
\hline $\begin{array}{l}\text { (22E)-3ß,6a,1 1-Trihydroxy-9,11-seco-5a-cholesta-7,22-dien-9-one (29) } \\
\text { Subergorgol I (29) }\end{array}$ & 14.7 & 57.9 & 3.94 \\
\hline (22E)-6,11-Diacetoxy-3-hydroxy-9,1 1-seco-5a-cholesta-7,22-dien-9-one (30) & 6.01 & 96.8 & 16.1 \\
\hline (22E)-3,6,11-Triacetoxy-9,11-seco-5a-cholesta-7,22-dien-9-one (31) & 12.1 & 96.8 & 8.00 \\
\hline Averufin (32) & 9.27 & $>136$ & $>14.7$ \\
\hline 8-O-methylnidurufin (33) & 14.4 & $>126$ & $>8.75$ \\
\hline Nidurufin (34) & $>65.1$ & $>130$ & UD \\
\hline Questinol (35) & $>83.3$ & $>167$ & UD \\
\hline$\omega$-Hydroxyrubrocristin (36) & $>79.1$ & $>158$ & UD \\
\hline Asperinine A (37) & 30.5 & $>87.7$ & $>2.88$ \\
\hline Asperinine B (38) & 39.5 & $>87.7$ & $>2.22$ \\
\hline Rhodoptilometrin (39) & 11.9 & 159 & 13.4 \\
\hline Variecolortide C (40) & $>82.9$ & $>82.9$ & UD \\
\hline 7-O-methylvariecolortide A (41) & $>74.5$ & $>74.5$ & UD \\
\hline Variecolortide B (42) & $>84.9$ & $>84.9$ & UD \\
\hline Dihydroxyisoechinulin A (43) & $>118$ & $>118$ & UD \\
\hline Echinulin (44) & $>54.2$ & $>108$ & UD \\
\hline Neoechinulin (45) & 46.4 & $>155$ & $>3.34$ \\
\hline Aspochalasin K (46) & 17.3 & $>115$ & $>6.65$ \\
\hline Aspochalasin E (47) & 32.2 & $>119$ & $>3.70$ \\
\hline Kipukasin H (48) & $>61.3$ & $>123$ & UD \\
\hline
\end{tabular}


Table 1 continued

\begin{tabular}{|c|c|c|c|}
\hline Compounds & $\mathrm{EC}_{50}$ & $\mathrm{LC}_{50}$ & $\mathrm{LC}_{50} / \mathrm{EC}_{50}$ \\
\hline Kipukasin E (49) & $>59.2$ & $>59.2$ & UD \\
\hline Kipukasin D (50) & $>59.2$ & $>59.2$ & UD \\
\hline Diacetylkipukasin E (51) & 44.5 & $>98.8$ & $>2.22$ \\
\hline Diacetylkipukasin D (52) & $>49.4$ & $>98.8$ & UD \\
\hline Penilumamide (53) & $>96.9$ & $>96.9$ & UD \\
\hline Penilumamide D (54) & $>58.8$ & $>58.8$ & UD \\
\hline Asperpeptide A (55) & $>46.6$ & $>46.6$ & UD \\
\hline Sea-Nine $211^{\mathrm{TM}}$ & 4.36 & 88.7 & 20.3 \\
\hline
\end{tabular}

UD undetectable

remarkably, 2,4,6,2',4',6'-hexabromo-diorcinol (13), displayed the most excellent antifouling activity, with an $\mathrm{EC}_{50}$ value of $0.71 \mu \mathrm{M}$, six times stronger than that of Sea-Nine $211^{\mathrm{TM}}$.

\section{Structure-activity relationship (SAR) of phenyl ether derivatives on antifouling activity}

Comparison of the natural phenyl ethers 1-6 indicated that 4-methoxyacyl-diorcinol (3) has the most strong activity $\left(\mathrm{EC}_{50}=7.43 \mu \mathrm{M}\right)$, while others showed moderate activity $\left(\mathrm{EC}_{50}=18.2-57.3 \mu \mathrm{M}\right)$. It should be noted that 3 displayed 4 times stronger activity than diorcinol (1) $\left(\mathrm{EC}_{50}=32.6 \mu \mathrm{M}\right)$, indicating that the ester group substitution at $\mathrm{C}-4$ could increase the activity. However, a hydroxy substitution at $\mathrm{C}-2$ as in $2\left(\mathrm{EC}_{50}=57.3 \mu \mathrm{M}\right)$ decreased the activity. Additionally, methoxy substituted at $\mathrm{C}-3$ in $4\left(\mathrm{EC}_{50}=31.0 \mu \mathrm{M}\right)$ was found no obvious change in activity.

To investigate the SAR of phenyl ethers on antifouling activity, $\mathbf{1}$ and $\mathbf{3}$ containing $3-\mathrm{OH}$ and $3^{\prime}-\mathrm{OH}$ with high yields were selected for structure modification by alkylation and acylation. Since the acylated product 3-O- $p$-bromobenzoyl-diorcinol (15) exhibited high activity, 1 and 3 were also modified by bromination to offer polybrominated diphenyl ether derivatives. All of the alkylated (7, 8 and 12) and acylated (9-11, 15) synthetic phenyl ether derivatives showed stronger antifouling activity $\left(\mathrm{EC}_{50}=2.23-27.9 \mu \mathrm{M}\right)$ than the original compound $\mathbf{1}$ (Table 1; Fig. 2). Of the alkylated derivatives, 7 with a propionyloxy group substitution at $\mathrm{C}-3$ had the most strong activity $\left(\mathrm{EC}_{50}=9.82 \mu \mathrm{M}\right)$. Among the acylated products, a benzoyloxy substitution at $\mathrm{C}-3(\mathbf{1 0})\left(\mathrm{EC}_{50}=12.6 \mu \mathrm{M}\right)$ increased the activity, while an acetoxy substitution (9) $\left(\mathrm{EC}_{50}=3.05 \mu \mathrm{M}\right)$ and a $p$-bromobenzoyl substitution (15) $\left(\mathrm{EC}_{50}=2.42 \mu \mathrm{M}\right)$ resulted in conspicuous increase in activity. Interestingly, it was found that the smaller acetoxy substitutions at $\mathrm{C}-3$ or/and $\mathrm{C}-3^{\prime}(\mathbf{9}, \mathbf{1 1})$ were better than the larger benzoyloxy substitution at C-3 (10). Additionally, the $p$-bromobenzoyl substitution (15) was better than the benzoyloxy substitution (10), suggesting that the introduction of bromine atom could increase the activity.

To further investigate the role of bromine atom in antifouling activity of phenyl ether derivatives, polybrominated diphenyl ether derivatives 13 and 14 were synthesized from $\mathbf{1}$ and $\mathbf{3}$ by the bromination reactions, respectively (Fig. 2; Additional file 1). It was found that both 13 and 14 displayed very strong anti-larval settlement activity with the $\mathrm{EC}_{50}$ values of $0.71 \mu \mathrm{M}$ and $1.17 \mu \mathrm{M}$, respectively. These results further demonstrated that the introduction of bromine atoms in the phenyl ether derivatives could significantly improve the antifouling activity.

The above investigation on SAR of phenyl ether derivatives on antifouling activity was summarized in Fig. 3. These discussion should be benefit for discovery and development for antifouling agents with high activity.

\section{Preliminary evaluation on the toxicity of antifouling phenyl ether derivatives}

It should be emphasized that the toxicity is a major concern of environmentally friendly marine antifouling agents (Qian et al. 2010; Shao et al. 2015). The $\mathrm{LC}_{50} / \mathrm{EC}_{50}$ ratio is considered as therapeutic ratio which is often used to evaluate the efficacy of an antifouling compound in relation to its toxicity and has been commonly used as a yardstick for a potential compound (Qian et al. 2010). A compound with a $\mathrm{LC}_{50} / \mathrm{EC}_{50}$ ratio $>15$ is often considered as a non-toxic antifouling compound, but a much higher $\mathrm{LC}_{50} / \mathrm{EC}_{50}$ ratio is highly recommended when screening candidate compounds (Fusetani 2011; Qian et al. 2010). In present study, the toxicities were tested (expressed as $\mathrm{LC}_{50}$ values) and the therapeutic ratios were evaluated for the active compounds. The active phenyl ether derivative 7 showed toxicity with the $\mathrm{LC}_{50} / \mathrm{EC}_{50}$ ratio of 11.4. Fortunately, the phenyl ether derivatives, 3, 9, 11, 13-15, demonstrated low/non-toxicity with high therapeutic ratios $\left(\mathrm{LC}_{50} / \mathrm{EC}_{50} \geq 21.1\right)$ (Table 1$)$. More remarkably, the polybrominated diphenyl ether derivative, 

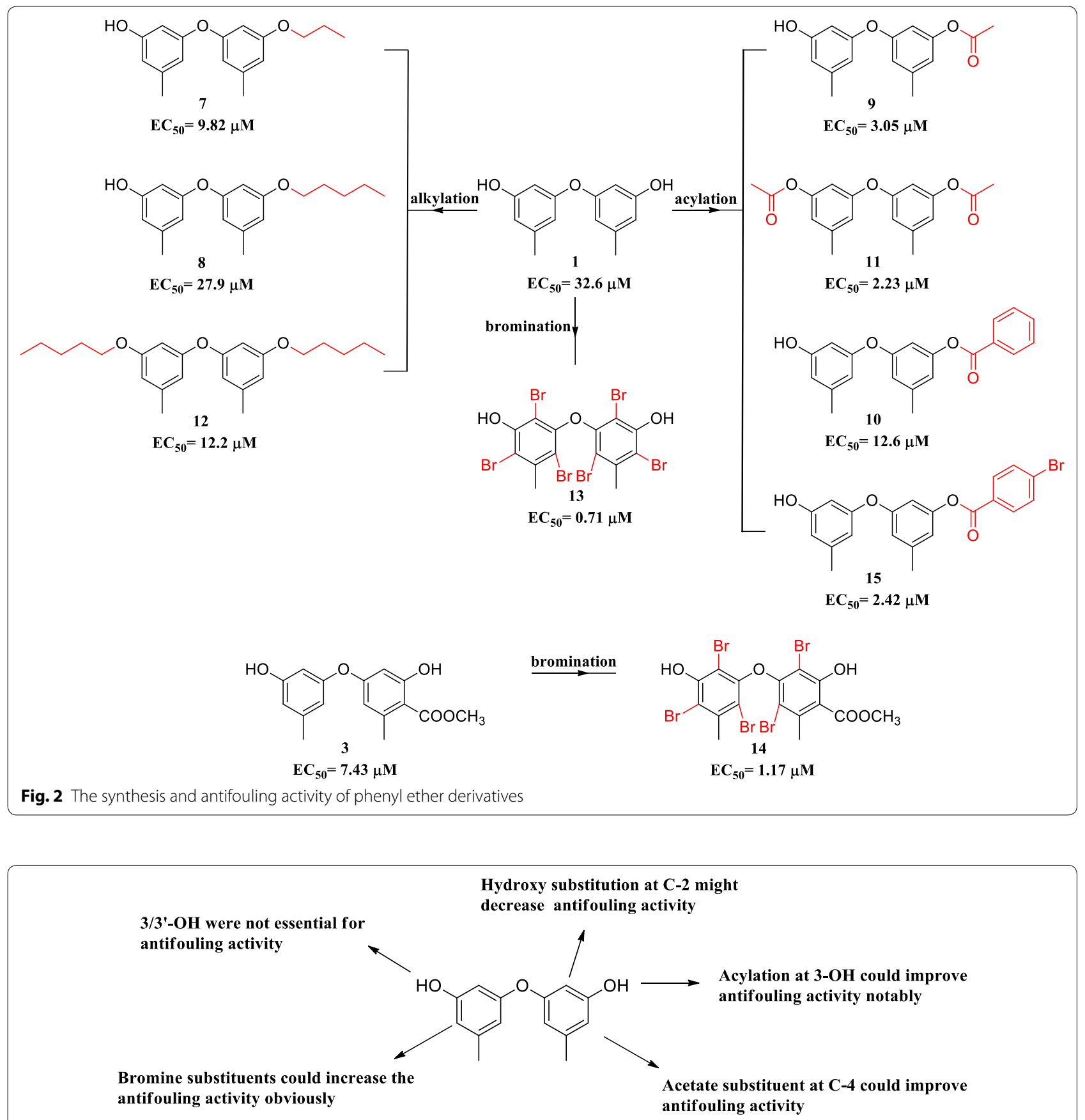

Fig. 3 Summarized antifouling structure-activity relationships (SAR) for phenyl ether derivatives

2,4,6,2', $4^{\prime}, 6^{\prime}$-hexabromo-diorcinol (13), was found to have a $\mathrm{LC}_{50} / \mathrm{EC}_{50}$ ratio up to 31.0 . It was suggested that 13 may be the most potent low/nontoxic antifouling candidate in the tested compounds.

To further evaluate the security of the antifouling active compounds, the brine shrimp lethality towards Artemia salina was also investigated. Brine shrimp is an aquatic crustacean belonging to a genus of Artemia, and this microfauna is widely used for screening in ecotoxicological studies (Lu et al. 2012) and testing the toxicity of chemicals (Lee et al. 2014). It was found that the phenyl ether derivatives 3, 9, 11, 13-15 showed non- or lowtoxicity $\left(\mathrm{LC}_{50} \geq 34.7 \mu \mathrm{M}\right)$ compared with the positive control adriamycin $\left(\mathrm{LC}_{50}=12.0 \mu \mathrm{M}\right)$ (Table 2). 
Table 2 Toxicity of phenyl ether derivatives (1-6, 9-11, 13-15) against brine shrimps Artemia salina

\begin{tabular}{llcl}
\hline Compounds & $\mathrm{LC}_{\mathbf{5 0}}(\boldsymbol{\mu M})$ & Compounds & $\mathrm{LC}_{\mathbf{5 0}}(\boldsymbol{\mu M})$ \\
\hline $\mathbf{1}$ & 126 & $\mathbf{1 0}$ & $>150$ \\
$\mathbf{2}$ & 126 & $\mathbf{1 1}$ & $>159$ \\
$\mathbf{3}$ & 34.7 & $\mathbf{1 3}$ & 35.6 \\
$\mathbf{4}$ & 41.0 & $\mathbf{1 4}$ & $>73.3$ \\
$\mathbf{5}$ & 172 & $\mathbf{1 5}$ & $>121$ \\
$\mathbf{6}$ & 164 & Adriamycin & 12.0 \\
$\mathbf{9}$ & 91.9 & & \\
\hline
\end{tabular}

\section{Antifouling activity of other compounds}

Besides the phenyl ether derivatives, other compounds were also found to have antifouling activity. Among the terpenoids (16-22), one diterpenoid (22) with two furan rings showed strong antifouling activity with the $\mathrm{EC}_{50}$ value of $6.05 \mu \mathrm{M}$, and one sesquiterpene (17) displayed moderate activity with $\mathrm{EC}_{50}$ value of $14.7 \mu \mathrm{M}$. Six 9,11-secosteroids $(23,25,26,29-31)$ and one cytochalasin (46) showed strong or moderate activity, of which 30 showed strong activity with an $\mathrm{EC}_{50}$ of $6.01 \mu \mathrm{M}$, which was close to the positive control Sea-Nine $211^{\mathrm{TM}}$ $\left(\mathrm{EC}_{50}=4.36 \mu \mathrm{M}\right)($ Table 1$)$. Unfortunately, most of the active compounds $(16,18,23,25,26,29,31)$ showed toxicity with the ratios of $\mathrm{LC}_{50} / \mathrm{EC}_{50}<15$. While the sesquiterpene (17), the diterpenoid (22) and the 9,11-secosteroid (30) showed low/non-toxicity with the ratios of $\mathrm{LC}_{50} / \mathrm{EC}_{50}>15$.

In conclusion, 55 isolated and structural modified compounds derived from gorgonians, sponge and their symbiotic fungi have been evaluated for their antifouling activities and toxicities. Ten compounds $(3,7,9,11$, 13-15, 22, 30, 32) exhibited strong antifouling activities against the larval settlement of barnacle $B$. amphitrite cyprids with the $\mathrm{EC}_{50}$ values lower than $10 \mu \mathrm{M}$. Five phenyl ether derivatives $(\mathbf{9}, \mathbf{1 1}, 13-15)$ exhibited potent antifouling activity with the $\mathrm{EC}_{50}$ values lower than $3.05 \mu \mathrm{M}$. Specifically, these five phenyl ether derivatives displayed low/non-toxicity with the $\mathrm{LC}_{50} / \mathrm{EC}_{50}$ ratios higher than 15. Preliminary SAR study of phenyl ethers revealed that the acetoxy groups and bromine substituents could significantly improve the antifouling activity. The polybrominated diphenyl ether derivative, 2,4,6,2',4',6'-hexabromo-diorcinol (13), which displayed the most excellent anti-larval settlement activity, was considered as a promising high-efficient, low/non-toxic and environmentfriendly antifouling candidate.

\section{Additional file}

Additional file 1. Structures, NMR and MS data of the 55 compounds.
Abbreviation

SAR: structure-activity relationship.

\begin{abstract}
Authors' contributions
Planning and designing of study: CYW, CLS, PYQ; experimentation: CYW, KLW, YX, MC, JJZ, ML; result analysis: CYW, CYW; manuscript drafting: CYW, CYW, CLS. All authors contributed in the final approval of manuscript. All authors read and approved the final manuscript.

\section{Author details}

${ }^{1}$ Key Laboratory of Marine Drugs, School of Medicine and Pharmacy, The Ministry of Education of China, Ocean University of China, 5 Yushan Road, Qingdao 266003, People's Republic of China. ${ }^{2}$ Laboratory for Marine Drugs and Bioproducts, Qingdao National Laboratory for Marine Science and Technology, Qingdao 266071, People's Republic of China. ${ }^{3}$ KAUST Global Collaborative Research, Division of Life Science, Hong Kong University of Science and Technology, Clear Water Bay, Hong Kong, People's Republic of China. ${ }^{4} \mathrm{Col}-$ lege of Life Science, Shenzhen University, 3688 Nanhai Ave, Shenzhen 518060, People's Republic of China. ${ }^{5}$ Institute of Evolution and Marine Biodiversity, Ocean University of China, Qingdao 266003, People's Republic of China.
\end{abstract}

\section{Acknowledgements}

This work was supported by the National Natural Science Foundation of China (41130858; 41322037), the Outstanding Youth Natural Science Foundation of Shandong Province (JQ201510), and the Taishan Scholars Program of Shandong, China.

\section{Competing interests}

The authors declare that they have no competing interests.

\section{Ethical approval}

All applicable institutional guidelines for the care and use of animals were followed. (Barnacle welfare and experimental procedures were strictly in accordance with the guide of Hong Kong University of Science and Technology, and brine shrimp welfare and experimental procedures were strictly in accordance with the guide of Ocean University of China). This article does not contain any studies with human participants performed by any of the authors.

\section{Funding}

This study was funded by the National Natural Science Foundation of China (Grant Numbers 41130858; 41322037), the Outstanding Youth Natural Science Foundation of Shandong Province (Grant Number JQ201510) and the Taishan Scholars Program of Shandong, China.

Received: 19 July 2016 Accepted: 14 October 2016

Published online: 26 October 2016

\section{References}

Aknin M, Costantino V, Mangoni A, Fattorusso E, Gaydou EM (1998) New 9,11-secosterols from gorgonian Subergorgia suberosa of the Indian Ocean. Steroids 63(11):575-578. doi:10.1016/50039-128X(98)00065-8

Anderson AP, Beveridge AA, Capon R (1994) Pharmacological properties of the natural marine product furospongin-1. Clin Exp Pharmacol. 21:945-953. doi:10.1111/j.1440-1681.1994.tb02656.x

Arai K, Aoki Y, Yamamoto Y (1989) Asperinines A and B, dimeric tetrahydroanthracene derivative from Aspergillus ruber. Chem Pharm Bull 37(3):621625. doi:10.1248/cpb.37.621

Bunyapaiboonsri T, Yoiprommarat S, Intereya K, Kocharin K (2007) New diphenyl ethers from the insect pathogenic fungus cordyceps sp. BCC 1861. Chem Pharm Bull 55(2):304-307. doi:10.1248/cpb.55.304

Chen ZF, Matsumura K, Wang H, Arellano SM, Yan XC, Alam I, Archer JAC, Bajic VB, Qian PY (2011) Toward an understanding of the molecular mechanisms of barnacle larval settlement: a comparative transcriptomic approach. PLoS ONE 6:e22913. doi:10.1371/journal.pone.0022913

Chen M, Shao CL, Fu XM, Xu RF, Zheng JJ, Zhao DL, She ZG, Wang CY (2013) Bioactive indole alkaloids and phenyl ether derivatives from a marinederived Aspergillus sp. fungus. J Nat Prod 76:547-553. doi:10.1021/ np300707x 
Chen GD, Bao YR, Huang YF, Hu D, Li XX, Guo LD, Li J, Yao XS, Gao H (2014a) Three pairs of variecolortide enantiomers from Eurotium sp. with caspase-3 inhibitory activity. Fitoterapia 92:252-259. doi:10.1016/j. fitote.2013.11.012

Chen M, Fu XM, Kong CJ, Wang CY (2014b) Nucleoside derivatives from the marine-derived fungus Aspergillus versicolor. Nat Prod Res 28:895-900. doi $: 10.1080 / 14786419.2014 .891114$

Chen M, Han L, Wang Y, Zhang XL, Wang CY (2014c) A new sesquiterpene from the Hainan gorgonian Menella kanisa Grassoff. Nat Prod Res 28:11471151. doi:10.1080/14786419.2014.918122

Chen M, Shao CL, Fu XM, Kong CJ, She ZG, Wang CY (2014d) Lumazine peptides Penilumamides B - D and the cyclic pentapeptide Asperpeptide A from a gorgonian-derived Aspergillus sp. fungus. J Nat Prod 77:16011606. doi:10.1021/np5001686

Chen M, Shao CL, Kong CJ, She ZG, Wang CY (2014e) A new anthraquinone derivative from a gorgonian-derived fungus Aspergillus sp. Chem Nat Compd 50:617-620. doi:10.1007/s10600-014-1037-2

Culioli G, Ortalo-Magné A, Valls R, Hellio C, Clare AS, Piovetti L (2008) Antifouling activity of meroditerpenoids from the marine brown alga Halidrys siliquosa. J Nat Prod 71:1121-1126. doi:10.1021/np070110k

Faÿ F, Linossier I, Peron JJ, Langlois V, Vallée-Rehel K (2007) Antifouling activity of marine paints: study of erosion. Prog Org Coat 60:194-206. doi:10.1016/j.porgcoat.2007.07.027

Fusetani N (2011) Antifouling marine natural products. Nat Prod Rep 28:400410. doi:10.1039/CONP00034E

Gao M, Li FC, Su RG, Wang K, Li XZ, Lu W (2014) Antifouling potential of the marine microalga Dunaliella salina. World J Microb Biot 30:2899-2905. doi:10.1039/CONP00034E

Gong DL, Wang XJ, Xiang ZD, Wang JD, Zhang H, Liu CX, Zhang J, Xiang WS (2011) Diphenyl etheric metabolites from Streptomyces sp. neau50. J Antibiot 64:465-467. doi:10.1038/ja.2011.25

Han L, Wang CY, Huang H, Shao CL, Liu QA, Qi J, Sun XP, Zhai P, Gu YC (2010) A new pregnane analogue from Hainan soft coral Scleronephthya gracillimum Kükenthal. Biochem Syst Ecol 38:243-246. doi:10.1016/j. bse.2009.12.030

Jäälaid R, Järving I, Pehk T, Parve O, Lille U (2001) Short synthesis of novel 9, 11-secosterols. Nat Prod Lett 15(4):221-228. doi:10.1080/10575630108041285

Jacobson AH, Willingham GL (2000) Sea-nine antifoulant: an environmentally acceptable alternative to organotin antifoulants. Sci Total Environ 258:103-110. doi:10.1016/50048-9697(00)00511-8

Jiao P, Mudur SV, Gloer JB, Wicklow DT (2007) Kipukasins, nucleoside derivatives from Aspergillus Wersicolor. J Nat Prod 70:1308-1311. doi:10.1021/ np0702411

Kitano Y, Akima C, Yoshimura E, Nogata Y (2011) Anti-barnacle activity of novel simple alkyl isocyanides derived from citronellol. Biofouling 27:201-205. doi:10.1080/08927014.2011.553282

Kong WW, Shao CL, Wang CY, Xu Y, Qian PY, Chen AN, Huang H (2012) Diterpenoids and steroids from gorgonian Subergorgia mollis. Chem Nat Compd 48:512-515. doi:10.1007/s10600-012-0294-1

Konstantinou IK, Albanis TA (2004) Worldwide occurrence and effects of antifouling paint booster biocides in the aquatic environment: a review. Environ Int 30:235-248. doi:10.1016/S0160-4120(03)00176-4

Koul SK, Taneja SC, Ibraham SP, Dhar KL, Atal CK (1985) A C-formylated azulene from Lactarius deterrimus. Phytochemistry 24:181-182. doi:10.1016/ S0031-9422(00)80834-1

Lee YM, Li HY, Hong JK, Cho HY, Bae KS, Kim MA, Kim D, Jung JH (2010) Bioactive metabolites from the sponge-derived fungus Aspergillus versicolor. Arch Pharm Res 33(2):231-235. doi:10.1007/s12272-010-0207-4

Lee MN, Kim SK, Li XH, Lee JH (2014) Bacterial virulence analysis using brine shrimp as an infection model in relation to the importance of quorum sensing and proteases. J Gen Appl Microbiol 60:169-174. doi:10.2323/ jgam.60.169

Li YL, Li XF, Kang JS, Chol HD, Son BW (2004) New radical scavenging and ultraviolet-A protecting prenylated dioxopiperazine alkaloid related to Isoechinulin A from a marine isolate of the fungus Aspergillus. J Antibiot 57(5):337-340. doi:10.190.7164/antibiotics.57.337

Li D, Xu Y, Shao CL, Yang RY, Zheng CJ, Chen YY, Fu XM, Qian PY, She ZG, de Voogd NJ, Wang CY (2012) Antibacterial bisabolane-type sesquiterpenoids from the sponge-derived fungus Aspergillus sp. Mar Drugs 10:234-241. doi:10.3390/md10010234
Li YX, Wu HX, Xu Y, Shao CL, Wang CY, Qian PY (2013) Antifouling activity of secondary metabolites isolated from Chinese marine organisms. Mar Biotechnol 15:552-558. doi:10.1007/s10126-013-9502-7

Liu M, Shao CL, Chen M, Qi J, Wang Y, Fang YC, Wang CY (2014a) Bioactive 9,11-secosteroids from gorgonian Subergorgia suberosa collected from the South China Sea. Chem Biodivers 11:1109-1120. doi:10.1002/ cbdv.201400021

Liu QA, Shao CL, Gu YC, Blum M, Gan LS, Wang KL, Chen M, Wang CY (2014b) Antifouling and fungicidal resorcylic acid lactones from the sea anemone-derived fungus Cochliobolus lunatus. J Agr Food Chem 62:3183-3191. doi:10.1021/jf500248z

Lu Y, Xu XL, LiT, XU YF, Wu X (2012) The use of a brine shrimp (Artemia salina) bioassay to assess the water quality in Hangzhou section of BeijingHangzhou grand canal. B Environ Contam Tox 88:472-476. doi:10.1007/ s00128-011-0498-2

Meyer BN, Ferrigni NR, Putnam JE, Jacobsen LB, Nichols DE, McLaughlin JL (1982) Brine shrimp: a convenient general bioassay for active plant constituents. Planta Med 45:31-34. doi:10.1055/s-2007-971236

Migliuolo A, Piccialli V, Sica D (1992) Two new 9,11-secosterols from the marine sponge Spongia officinalis. synthesis of 9,11-seco33,6a,11-trihydroxy-5a-cholest-7-en-9-one. Steroids 57(7):344-347. doi:10.1016/0039-128X(92)90054-D

Nagasawa H, Isogai A, Ikeda K, Sato S, Murakoshi S, Suzuki A, Tamura S (1975) Isolation and structure elucidation of a new indole metabolite from Aspergillus ruber. Agr Biol Chem 39(9):1901-1902. doi:10.1080/00021369. 1975.10861879

Naruse N, Yamamoto H, Murta S, Sawada Y, Fukagawa Y, Oki T (1993) Aspochalasin $\mathrm{E}$, a new antibiotic isolated from a fungus. J Antibiot 46(4):679-681. doi:10.7164/antibiotics.46.679

Newman DJ, Cragg GM (2004) Advanced preclinical and clinical trials of natural products and related compounds from marine sources. Curr Med Chem 11:1693-1713. doi:10.2174/0929867043364982

Nozoe T, Takekuma S, Doi M, Matsubara Y, Yamamoto H (1984) Oxidation of azulene derivatives Autoxidation of guaiazulene in a polar aprotic solvent. Chem Lett. doi:10.1246/cl.1984.627

Omae I (2003) Organotin antifouling paints and their alternatives. Appl Organomet Chem 17:81-105. doi:10.1002/aoc.396

Pérez M, García M, Stupak M, Blustein G (2014) Synthesis and characterization of ferric sorbate and aluminum sorbate as antifouling pigments for marine paints. Ind Eng Chem Res 53:3570-3577. doi:10.1021/ie403905v

Podojil M, Sedmera P, Vokoun J, Betina V, Baráthová H, Ďuračková Z, Horáková K, Nemec P (1979) Eurotium (Aspergillus) repens metabolites and their biological activity. Folia Microbiol 23:438-443. doi:10.1007/BF02885572

Qian PY, Xu Y, Fusetani N (2010) Natural products as antifouling compounds: recent progress and future perspectives. Biofouling 26:223-234. doi:10.1080/08927010903470815

Raveendran TV, Mol VPL (2009) Natural product antifoulants. Curr Sci India 97:508-520

Ren H, Liu W (2011) Nidurufin as a new cell cycle inhibitor from marinederived fungus Penicillium flavidorsum SHK1-27. Arch Pharm Res 34(6):901-905. doi:10.1007/s12272-011-0606-1

Rittschof D (2001) Natural product antifoulants and coatings development. In: Clintock JB, Baker BJ (eds) Marine chemical ecology. Taylor \& Francis, Abingdon, pp 543-566. doi:10.1201/9781420036602.ch17

Sato K, Ozu T, Takenaga N (2013) Solvent-free synthesis of azulene derivatives via Passerini reaction by grinding. Tetrahedron Lett 54:661-664. doi:10.1016/j.tetlet.2012.11.148

Shao CL, Wang CY, Wei MY, Gu YC, She ZG, Qian PY, Lin YC (2011a) Aspergilones $A$ and $B$, two benzylazaphilones with an unprecedented carbon skeleton from the gorgonian-derived fungus Aspergillus sp. Bioorg Med Chem Lett 21:690-693. doi:10.1016/j.bmcl.2010.12.005

Shao CL, Wu HX, Wang CY, Liu QA, Xu Y, Wei MY, Qian PY, Gu YC, Zheng CJ, She ZG, Lin YC (2011b) Potent antifouling resorcylic acid lactones from the gorgonian-derived fungus Cochliobolus lunatus. J Nat Prod 74:629-633. doi:10.1021/np100641b

Shao CL, Xu RF, Wang CY, Qian PY, Wang KL, Wei MY (2015) Potent antifouling marine dihydroquinolin-2(1H)-one-containing alkaloids from the gorgonian coral-derived fungus Scopulariopsis sp. Mar Biotechnol 17:408-415. doi:10.1007/s10126-015-9628-x

Slater GP, Haskins RH, Hogge LR (1971) Metabolites from a Chrysosporium species. Can J Microbiol 17:1576-1579. doi:10.1139/m71-252 
Solis PN, Wright CW, Anderson MM, Gupta MP, Phillipson JD (1993) A microwell cytotoxicity assay using Artemia salina (brine shrimp). Planta Med 59:250-252. doi:10.1055/s-2006-959661

Sun XP, Wang CY, Shao CL, Li L, Li XB, Chen M, Qian PY (2010) Chemical constituents of the soft coral Sarcophyton infundibuliforme from the South China Sea. Nat Prod Commun 5:1171-1174

Sun XP, Shao CL, Wang CY, Li XB, Xu Y, Qian PY, Zhao K, Zheng CJ (2012) Steroids of soft coral Scleronephthya sp. from the South China Sea. Chem Nat Compd 48:341-343. doi:10.1007/s10600-012-0245-x

Talzhanov NA, Raldugin VA, Shakirov MM, Atazhanova GA, Adekenov SM (2005) Formation of an unusual guaiane ketopentaenolide from dehydroisoleucomisin by the action of anhydrous DMF and $\mathrm{HCl}$. Chem Nat Compd 41(4):420-422. doi:10.1007/s10600-005-0167-y

Wang WL, Zhu TJ, Tao HW, Lu ZY, Fang YC, Gu QQ, Zhu WM (2007) Three novel, structurally unique spirocyclic alkaloids from the halotolerant B-17 fungal strain of Aspergillus variecolor. Chem Biodivers 4:2913-2919. doi:10.1002/ cbdv.200790240

Wang CY, Chen AN, Shao CL, Li L, Xu Y, Qian PY (2011) Chemical constituents of soft coral Sarcophyton infundibuliforme from the South China Sea. Biochem Syst Ecol 39:853-856. doi:10.1016/j.bse.2011.04.005

Wang KL, Xu Y, Lu L, Li YX, Han Z, Zhang J, Shao CL, Wang CY, Qian PY (2015) Low-toxicity diindol-3-ylmethanes as potent antifouling compounds. Mar Biotechnol 17:624-632. doi:10.1007/s10126-015-9656-6
Wright AD, Nielson JL, Tapiolas DM, Motti CA, Ovenden SPB, Kearns PS, Liptrot $\mathrm{CH}$ (2009) Detailed NMR, including 1,1-ADEQUATE, and anticancer studies of compounds from the echinoderm Colobometra perspinosa. Mar Drugs 7:565-575. doi:10.3390/md7040565

Xu Y, He HP, Schulz S, Liu X, Fusetani N, Xiong HR, Xiao X, Qian PY (2010) Potent antifouling compounds produced by marine Streptomyces. Bioresource Technol 101:1331-1336. doi:10.1016/j.biortech.2009.09.046

Zhang G, Tang XL, Cheng CL, Gong KK, Zhang XW, Zhu HY, Wu RC, Li PL, Li GQ (2013) Cytotoxic 9,11-secosteroids from the South China Sea gorgonian Subergorgia suberosa. Steriods 78(9):845-850. doi:10.1016/j. steroids.2013.05.009

Zheng JJ, Shao CL, Chen M, Gan LS, Fang YC, Wang XH, Wang CY (2014) Ochracenoids A and B, guaiazulene-based analogues from gorgonian Anthogorgia ochracea collected from the South China Sea. Mar Drugs 12:1569-1579. doi:10.3390/md12031569

Zhou GX, Wijeratne EMK, Bigelow D, Pierson LS, VanEtten HD, Gunatilaka AAL (2004) Aspochalasins I, J, and K: three new cytotoxic cytochalasans of Aspergillus flavipes from the rhizosphere of Ericameria laricifolia of the sonorant desert. J Nat Prod 67(3):328-332. doi:10.1021/np030353m

Zhou YM, Shao CL, Wang CY, Huang H, Xu Y, Qian PY (2011) Chemical constituents of the gorgonian Dichotella fragilis (Ridleg) from the South China Sea. Nat Prod Commun 6:1239-1242

\section{Submit your manuscript to a SpringerOpen ${ }^{\odot}$ journal and benefit from:}

- Convenient online submission

- Rigorous peer review

- Immediate publication on acceptance

- Open access: articles freely available online

- High visibility within the field

- Retaining the copyright to your article

Submit your next manuscript at springeropen.com 